\title{
Optimization of Production of Bread Enriched With Leafy Vegetable Powder
}

\author{
Famuwagun AA ${ }^{1 *}$, Taiwo KA ${ }^{1}$, Gbadamosi SO$^{1}$ and Oyedele $\mathrm{DJ}^{2}$
}

${ }^{1}$ Department of Food Science and Technology, Obafemi Awolowo University, Ile-Ife, Nigeria

${ }^{2}$ Faculty of Agriculture, Department of Soil and Land Management, Obafemi Awolowo University, Ile-Ife, Nigeria

\begin{abstract}
Box-Behnken design was used to study the effect of level of inclusion of dried leafy vegetable powder, mixing time and proofing time, on the weight, volume and specific volume of bread made from composite flour. Data obtained were evaluated using regression analysis. The study revealed all the parameters studied were significant in producing high quality vegetable powder enriched bread. The coefficient determination $\left(\mathrm{R}^{2}\right)$ was good for the second-order quadratic model. The study found out those combinations of the parameters; level of vegetable inclusion; 3.65\%, proofing time: 90.6 minutes and mixing time: 4.04 minutes were the optimal conditions for the productions of high quality bread enriched with vegetable powder. The study further confirmed through additional analysis that the model is adequate to optimize the process.
\end{abstract}

Keywords: Vegetable powder; Proofing time; Mixing time; BoxBehnken design

\section{Introduction}

Bread is a baked product made from wheat flour. It is one of the most important staple foods in the world and the technology for its production has been in existence for long. There are evidences from food consumption survey in Nigeria of the astronomic rise in the consumption of this baked food [1]. In addition to wheat flour, which is the basic ingredient in bread, yeast, butter, salt, sugar and water are also important ingredients [2]. Other food materials like beverages can also be added based on individual delight. Each of the ingredients has its peculiar purpose in improving the physical characteristics of the final product. Bread, despite lack of some basic nutrients, it is generally accepted and of as such belong to class of food people called 'convenience food' [3].

Leafy vegetables represent inexpensive but high quality nutritional sources, for the poor segment of the population especially where malnutrition is on the increase. They represent a veritable natural pharmacy of minerals, vitamins and phytochemicals [4]. The fibre content of vegetables contributes to the feeling of satisfaction and prevents constipation while the proteins in vegetables are superior to those found in fruits [4]. Fluted pumpkin (Telfairia occedentalis) belongs to that class of leafy vegetable that is nutritionally and medicinally beneficial to human health [5]. The bioactive potentials of this vegetable have also been recognized.

The United States Department of Agriculture [6] food pyramids suggest a minimum of three serving of leafy greens per week. Most people fall short of this recommendation. Most health experts agree that the amount of leafy greens that we should consume is likely much higher than just three serving per week. The question that comes to mind is how to meet the recommendations for better health. Improving the nutritional base of a convenience food like bread with highly nutritious vegetable like fluted pumpkin will be a step in the right direction.

Recently, efforts are being made towards improving the quality of wheat bread through wheat flour substitution, probably due to perceived loss in some of nutrient of the wheat flour during milling. Composite flour is a partial replacement of wheat flour with other food materials such as vegetable flour [7]. However, in a bid to enrich the nutrient base of this bread with vegetable powder, some physical characteristics must not be compromised. In preserving the physical characteristics, such as loaf volume, weight and specific volume of bread enriched with vegetable powder, unit operations such as mixing time, level of vegetable inclusion and proofing time need to be optimized.

Bread, a basic food for human, has no negative health effects when produced in appropriate conditions using appropriate materials [8]. However, improper use of raw materials and non-optimal unit operations such as proofing time, mixing time can affect the physical characteristics of the product and hence, attractions of this product to consumers. Over-mixing or under-mixing of dough during baking process would have negative effect on the quality of the product. Overproofing or under-proofing also has effect on the actions of the yeast which affect the quality of the final product. Optimization method could be a veritable tool in determining the favourable production conditions for bread enriched with leafy vegetable powder.

The optimization of process parameters can be done by various techniques; one of the effective and commonly used techniques for this purpose is Response Surface Methodology, which is a collection of statistical and mathematical techniques useful for developing, improving and optimizing processes [9]. This technique is a faster and economical method for gathering research results than classic one variable at a time or full factors experimentation [10]. This statistical tool has been used in the optimization of bread by varying the amount of bran, the amount of yeast and the fermentation time on the amount of phytic acid in bread [11]. Mohammed and Sharif [12] optimized composite flour for the production of enhanced storability of leavened flat bread using response surface methodology.

This present study aims at optimizing some critical unit operations in the production of bread enriched with leafy vegetable powder such as mixing and proofing time and the level of inclusion of the vegetable powder on the loaf volume, weight and specific volume of the product. This would ultimately help the industry to gain economic advantage with increased production of high quality vegetable enriched bread.

*Corresponding author: Famuwagun AA, Food chemistry and processing Laboratory, Department of Food Science and Technology, Obafemi Awolowo University, lle-Ife, Nigeria, Tel: +2347038688258; E-mail: akinsolaalbert@gmail.com

Received June 10, 2016; Accepted June 29, 2016; Published July 04, 2016

Citation: Famuwagun AA, Taiwo KA, Gbadamosi SO, Oyedele DJ (2016) Optimization of Production of Bread Enriched With Leafy Vegetable Powder. J Food Process Technol 7: 605. doi:10.4172/2157-7110.1000605

Copyright: (C) 2016 Famuwagun AA, et al. This is an open-access article distributed under the terms of the Creative Commons Attribution License, which permits unrestricted use, distribution, and reproduction in any medium, provided the original author and source are credited. 


\section{Materials and Methods}

\section{Preparation of vegetable powder}

The leafy vegetable powder was prepared by modified method of Abraham et al. [13]. Fresh and matured fluted pumpkin (Telfaria occidentalis) leaves were obtained from Teaching and Research farms of Obafemi Awolowo University, Ile-Ife, Nigeria. The fresh vegetables were sorted, de-stalked and rinsed with clean water. The cleaned leafy vegetable was sliced to dimensions $(0.12 \times 0.90 \times 0.50 \mathrm{~mm})$ with clean knife. The sliced vegetables were dried using hot air cabinet drier at $<60^{\circ} \mathrm{C}$ for $8 \mathrm{hrs}$. The dried vegetable leaves were milled to fine powder using Marlex Excella dry mill (Marlex Appliances PVT, Daman).

\section{Preparation of composite flour blends}

Wheat flour was blended with $1 \%, 3 \%$ and $5 \%$ of dried, milled, fluted pumpkin leaf powder. The composite flour was mixed together to produce $200 \mathrm{~g}$ blends of each level of vegetable incorporation. The composite flours were then stored in air-tight container for further use.

\section{Baking of wheat flour bread enriched with vegetable powder}

Dough from the composite flour blends were baked using the straight-dough method of Greene and Bovell [14] with some modifications. The formula used in this process is: $200 \mathrm{~g}$ of composite flour blends (wheat flour and vegetable powder in different proportions), 6 g yeast, $4.0 \mathrm{~g}$ salt, $10 \mathrm{~g}$ shortening, $6 \mathrm{~g}$ sugar, and 120 $\mathrm{ml}$ water. All dry ingredients were weighed and placed in a Kenwood dough mixer (Model A 907 D) set at highest speed and mixed for 50 seconds. Then a suspension of the yeast in water was added. The mixture was further run at high speed for 50 seconds. Water was added to the mixture to make up the required water for the process for the process and the mixture was further mixed for the required length of time. The dough was later kneaded on the kneading table, rounded into balls by hand and placed in lightly greased fermentation bowl and placed in fermentation cabinet (National Company, Lincoln, NE). The dough was then proofed for the required length of time. Baking was done at $250^{\circ} \mathrm{C}$ for 15 minutes. The baked bread was allowed to cool at room temperature before measurements were taken.

\section{Determination of responses}

Volume, weight and specific volume of loaves produced: Loaf volume was measured by small seeds displacement method described by Khalil et al. [15]. Loaf was placed in a container of known volume into which rapeseeds was run until the container was full. The volume of seeds displaced by the loaf was considered as the loaf volumes which were measured in a graduated cylinder. The weight of the loaf was determined using a sensitive weighing balance and the specific volume of the loaf was determined by averaging the loaf volume with loaf weight.

$$
\text { Specific volume }\left(\mathrm{cm}^{3} / \mathrm{g}\right)=\frac{\text { loaf volume }}{\text { loaf weight }}
$$

Experimental design: The study employed Box-Behnken designs (BBD) of response surface methodology with three levels. The process was optimized on the basis of three input variables whose interactions were studied as three major responses. These input variables were determined on the basis of preliminary single experimental factor. The levels of various input variables selected are as follows; Inclusion of vegetable powder: $1-5 \%(\mathrm{w} / \mathrm{w})$, dough mixing time: 3-5 minutes and proofing time; $60-120$ minutes. The analyses of all the responses were done in triplicates and the average values reported. Factors and their levels for Box-Behnken design are shown in Table 1. The independent variables and dependent ones in coded form and the number of experimental runs are presented in Table 2. The selected responses evaluated include; loaf volume, loaf weight and specific volume. Seventeen runs (Table 2) were evaluated to select the best combination of processing conditions that produced the best quality of loaf of bread made from the composite flours.

Statistical analysis of the data: Data were analysed using Response Surface Methodology, Design-expert software version 8.0.3.1 (StatEase Inc., Minneapolis, USA). Data obtained from the experiment were fitted in the second order polynomial model and co-efficient for the regression equations were obtained.

The suitability of the fit was evaluated using analysis of variance (ANOVA). The fitted quadratic response is shown below:

$$
\mathrm{Y}_{\mathrm{i}}=\beta_{0}+\sum_{j=1}^{k} \beta_{j} X_{j} \sum_{j=1}^{k} \beta_{j j} X_{j j}+\sum_{i>j=1}^{k} \beta_{i j} X_{i} X_{j}+e \cdots \cdots
$$

In equation 1 above, $Y_{i}=$ predicted response, $\beta_{0}=$ a constant, $\beta j$ $=$ linear coefficient, $\beta j j=$ squared coefficient, and $\beta i j=$ interaction coefficient, $X i$ and $X j$ are the independent variables and $e$ the error, respectively.

\section{Results and Discussion}

\section{Model evaluation}

The optimization of the loaf volume, loaf weight and specific volume of bread made from composite flours comprising wheat flour

\begin{tabular}{|c|c|c|c|c|}
\hline \multirow{2}{*}{ Variables } & \multirow{2}{*}{ Code } & \multicolumn{3}{|c|}{ Range and Level } \\
\cline { 3 - 5 } & & $\mathbf{- 1}$ & $\mathbf{0}$ & $\mathbf{+ 1}$ \\
\hline $\begin{array}{c}\text { Level of veg. } \\
\text { inclusion (\%) }\end{array}$ & $\mathrm{A}$ & 1 & 3 & 5 \\
\hline Mixing time (min) & B & 3 & 4 & 5 \\
\hline Proofing time (min) & C & 60 & 90 & 120 \\
\hline
\end{tabular}

$\mathrm{A}=$ Level of veg. powder inclusion (\%); $\mathrm{B}=$ Mixing time $(\min ) ; \mathrm{C}=$ Proofing time (min).

Table 1: Experimental ranges and levels of the independent variables for the

\begin{tabular}{|c|c|c|c|c|c|c|}
\hline Runs & $\begin{array}{l}\text { Level of veg } \\
\text { inclusion }(\%)\end{array}$ & $\begin{array}{c}\text { Mixing } \\
\text { time (min) }\end{array}$ & $\begin{array}{l}\text { Proofing } \\
\text { time }(\mathrm{min})\end{array}$ & $\begin{array}{l}\text { Weight of } \\
\text { loaf }(g)\end{array}$ & $\begin{array}{c}\text { Volume } \\
\text { of loaf } \\
\left(\mathrm{cm}^{3}\right)\end{array}$ & $\begin{array}{l}\text { Specific } \\
\text { volume } \\
\left(\mathrm{cm}^{3} / \mathrm{g}\right)\end{array}$ \\
\hline 1 & -1 & 0 & 0 & 126.51 & 400 & 3.16 \\
\hline 2 & 0 & 1 & 1 & 142.16 & 415 & 2.92 \\
\hline 3 & 1 & 0 & 1 & 127.98 & 380 & 2.97 \\
\hline 4 & 0 & 0 & 0 & 158.58 & 635 & 4.00 \\
\hline 5 & 1 & 1 & 0 & 142.98 & 470 & 3.29 \\
\hline 6 & 0 & 1 & -1 & 140.90 & 412 & 2.92 \\
\hline 7 & 1 & 0 & -1 & 143.09 & 320 & 2.24 \\
\hline 8 & 0 & 0 & 0 & 168.80 & 570 & 3.39 \\
\hline 9 & 1 & 0 & 1 & 136.90 & 350 & 2.56 \\
\hline 10 & 0 & 1 & -1 & 123.64 & 430 & 3.48 \\
\hline 11 & 1 & -1 & 0 & 143.53 & 310 & 2.16 \\
\hline 12 & 1 & 1 & 0 & 140.89 & 500 & 3.55 \\
\hline 13 & 0 & 0 & 0 & 165.80 & 625 & 3.76 \\
\hline 14 & 1 & -1 & 0 & 140.30 & 340 & 2.42 \\
\hline 15 & 0 & -1 & 1 & 144.05 & 420 & 2.92 \\
\hline 16 & 0 & 0 & 0 & 162.85 & 620 & 3.81 \\
\hline 17 & 0 & 0 & 0 & 165.98 & 618 & 3.72 \\
\hline
\end{tabular}
experimental design.

Table 2: Box-Behnken experimental design for three factors in coded and uncoded units and the actual responses. 
Citation: Famuwagun AA, Taiwo KA, Gbadamosi SO, Oyedele DJ (2016) Optimization of Production of Bread Enriched With Leafy Vegetable Powder. J Food Process Technol 7: 605. doi:10.4172/2157-7110.1000605

Page 3 of 7

and green leafy vegetable powder was evaluated in this section. The coefficient of the regression equations for the measured responses, the linear, quadratic and interaction terms of the selected variables were evaluated and values shown in Table 3.

The results of the loaves weight of the bread showed that two linear $(\mathrm{A}, \mathrm{B})$, three quadratic $\left(\mathrm{A}^{2}, \mathrm{~B}^{2}, \mathrm{C}^{2}\right)$ parameters and one interaction $(\mathrm{BC})$ term were significant at $p<0.05$ as shown in Table 3 . For the loaf volume, it was shown from the analysis that two linear $(\mathrm{A}, \mathrm{C})$ parameters, three quadratic $\left(\mathrm{A}^{2}, \mathrm{~B}^{2}, \mathrm{C}^{2}\right)$ and one interaction terms were significant at $\mathrm{p}<0.05$ and two of the interaction terms were not significant. In the case of the specific volume of the loaves of bread produced, all the three linear $(A, B, C)$ terms and the three quadratic were significant terms. One interaction term (BC) was also significant. Just like the loaf weight and volume, two of the interaction terms were not significant.

\section{Fitting of the quadratic model}

The quadrating models fitting are shown in Table 4. From the analysis of variance (ANOVA), it was clear that the model was significant $(\mathrm{p}<0.05)$ for the predicted loaf volume, loaf weight and the specific volume of the vegetable powder enriched bread. The correlation coefficient $\left(\mathrm{R}^{2}\right)$ 0.9239, 0.9602 and 0.9684 for loaf weight, loaf volume,

\begin{tabular}{|c|c|c|c|c|c|c|}
\hline Parameter & $\begin{array}{l}\text { Co-efficient } \\
\text { Estimate }\end{array}$ & $\begin{array}{l}\text { Standard } \\
\text { Error }\end{array}$ & $95 \%$ CI Low & $\begin{array}{l}95 \% \mathrm{Cl} \\
\text { High }\end{array}$ & $t$ ratio & Prob $>t$ \\
\hline \multicolumn{7}{|c|}{ Loaf Weight } \\
\hline Intercept & 164.4 & 2.62 & 158.2 & 170.61 & 62.75 & 0.0032 \\
\hline A & 3.19 & 2.07 & -1.71 & 8.1 & 1.53 & 0.0016 \\
\hline B & -2.58 & 2.07 & -7.48 & 2.33 & -1.25 & 0.025 \\
\hline $\mathrm{C}$ & 2.12 & 2.07 & -2.79 & 7.02 & 1.02 & 0.341 \\
\hline$A B$ & -0.31 & -7.24 & 6.63 & 1 & 0.042 & 0.9195 \\
\hline$A C$ & -1.91 & -8.85 & 5.02 & 1 & 0.215 & 0.5348 \\
\hline $\mathrm{BC}$ & 4.79 & 2.93 & 11.72 & 1 & 1.635 & 0.0468 \\
\hline$A^{2}$ & 13.28 & 2.86 & -6.52 & 1.01 & 4.643 & 0.0024 \\
\hline $\mathrm{B}^{2}$ & 9.22 & 2.86 & -2.45 & 1.01 & 3.224 & 0.0146 \\
\hline$C^{2}$ & 17.5 & 2.86 & -10.74 & 1.01 & 6.119 & 0.0005 \\
\hline \multicolumn{7}{|c|}{ Loaf Volume } \\
\hline Intercept & 613.6 & 15.37 & 577.25 & 649.95 & 39.922 & 0.0014 \\
\hline$A$ & -53.75 & 12.15 & -82.48 & -25.02 & -4.434 & 0.0031 \\
\hline B & 10.38 & 12.15 & -18.36 & 39.11 & 0.854 & 0.4215 \\
\hline $\mathrm{C}$ & 0.38 & 12.15 & -28.36 & 39.11 & 0.031 & 0.00097 \\
\hline$A B$ & 0 & 17.18 & -40.64 & 40.64 & 0 & 1 \\
\hline$A C$ & 12.5 & 17.18 & -28.14 & 53.14 & 0.728 & 0.4906 \\
\hline$B C$ & -3.25 & 17.18 & -43.89 & 37.39 & -0.189 & 0.044 \\
\hline$A^{2}$ & -132.67 & 16.75 & -172.28 & -93.07 & -7.921 & 0.0001 \\
\hline $\mathrm{B}^{2}$ & -75.93 & 16.75 & -115.53 & -36.32 & 4.533 & 0.0027 \\
\hline $\mathrm{C}^{2}$ & -118.42 & 16.75 & -158.03 & -78.82 & 7.07 & 0.0002 \\
\hline \multicolumn{7}{|c|}{ Specific Volume } \\
\hline Intercept & 3.74 & 0.1 & 3.5 & 3.98 & 37.4 & 0.0034 \\
\hline A & -0.45 & 0.081 & -0.64 & -0.26 & -5.556 & 0.0008 \\
\hline$B$ & 0.14 & 0.081 & -0.056 & 0.33 & 1.728 & 0.0137 \\
\hline $\mathrm{C}$ & -0.054 & 0.11 & -0.24 & 0.14 & -0.491 & 0.0025 \\
\hline$A B$ & 0 & 0.11 & -0.27 & 0.27 & 0 & 1 \\
\hline$A C$ & 0.13 & 0.11 & -0.14 & 0.4 & 1.182 & 0.3001 \\
\hline$B C$ & -0.13 & 0.11 & -0.41 & 0.13 & -1.182 & 0.0258 \\
\hline$A^{2}$ & -0.6 & 0.11 & -0.87 & -0.34 & -5.455 & 0.001 \\
\hline $\mathrm{B}^{2}$ & -0.28 & 0.11 & -0.54 & -0.014 & -2.545 & 0.0415 \\
\hline $\mathrm{C}^{2}$ & -0.4 & 0.11 & -0.66 & -0.14 & -3.636 & 0.0088 \\
\hline \multicolumn{7}{|c|}{ Values in bold form statistically different at $p<0.05$} \\
\hline
\end{tabular}

Table 3: Regression co-efficient, standard error, t-test confidence level. results of the response surface for loaf weight, loaf volume and specific volume of loaves.

\begin{tabular}{|c|c|c|c|c|c|}
\hline \multicolumn{7}{|c|}{ Weight of loaves } \\
\hline Source & SS & Df & MS & F-value & p-value \\
\hline Model & 2924.01 & 9 & 324.89 & 9.44 & $\mathbf{0 . 0 0 3 7}$ \\
\hline A & 81.8 & 1 & 81.6 & 2.37 & $\mathbf{0 . 0 0 1 6}$ \\
\hline $\mathrm{B}$ & 53.06 & 1 & 53.06 & 1.54 & $\mathbf{0 . 0 2 5}$ \\
\hline $\mathrm{C}$ & 35.93 & 1 & 35.93 & 1.04 & 0.341 \\
\hline $\mathrm{AB}$ & 0.38 & 1 & 0.38 & 0.011 & 0.9195 \\
\hline $\mathrm{AC}$ & 14.67 & 1 & 14.67 & 0.43 & 0.5348 \\
\hline $\mathrm{BC}$ & 91.65 & 1 & 91.65 & 2.66 & $\mathbf{0 . 0 4 6 8}$ \\
\hline $\mathrm{A}^{2}$ & 743 & 1 & 743 & 21.58 & $\mathbf{0 . 0 0 2 4}$ \\
\hline $\mathrm{B}^{2}$ & 357.59 & 1 & 357.59 & 10.39 & $\mathbf{0 . 0 1 4 6}$ \\
\hline $\mathrm{C}^{2}$ & 1289.2 & 1 & 1289.2 & 37.45 & $\mathbf{0 . 0 0 0 5}$ \\
\hline Residual & 240.99 & 7 & 34.43 & & \\
\hline Lack of fit & 180.9 & 3 & 60.3 & 4.01 & 0.1064 \\
\hline Experimental Error & 60.09 & 4 & 15.02 & & \\
\hline R & 1 & & & \\
\hline
\end{tabular}

$R^{2}=92.39 \% ;$ Adjusted $R^{2}=92.60 \% ;$ Predicted $R^{2}=85.58 \%$

\begin{tabular}{|c|c|c|c|c|c|}
\hline \multicolumn{7}{|c|}{ Volume of loaves } \\
\hline Source & SS & Df & MS & F-value & p-value \\
\hline Model & 199000 & 9 & 22152.51 & 18.75 & $\mathbf{0 . 0 0 0 4}$ \\
\hline A & 23112.5 & 1 & 23112.5 & 19.57 & $\mathbf{0 . 0 0 3 1}$ \\
\hline B & 861.13 & 1 & 861.13 & 0.73 & 0.4215 \\
\hline C & 1.13 & 1 & 1.13 & 9.524 & $\mathbf{0 . 0 0 0 9 7}$ \\
\hline AB & 0 & 1 & 0 & 0 & 1 \\
\hline AC & 625 & 1 & 625 & 0.53 & 0.4906 \\
\hline BC & 42.25 & 1 & 42.25 & 0.036 & $\mathbf{0 . 0 5 4 4}$ \\
\hline $\mathrm{A}^{2}$ & 74116.44 & 1 & 74116.44 & 62.74 & $\mathbf{0 . 0 0 0 1}$ \\
\hline $\mathrm{B}^{2}$ & 24272.02 & 1 & 24272.02 & 20.55 & $\mathbf{0 . 0 0 2 7}$ \\
\hline $\mathrm{C}^{2}$ & 59050.44 & 1 & 59050.44 & 49.99 & $\mathbf{0 . 0 0 0 2}$ \\
\hline Residual & 8268.95 & 7 & 1181.28 & & \\
\hline Lack of fit & 5719.75 & 3 & 1906.58 & 2.99 & 0.1587 \\
\hline Experimental Error & 2549.2 & 4 & 637.3 & & \\
\hline R. & & 1 & & & \\
\hline
\end{tabular}

$\mathrm{R}^{2}=96.02 \%$; Adjusted $\mathrm{R}^{2}=90.90 \%$; Predicted $\mathrm{R}^{2}=84.01 \%$

\begin{tabular}{|c|c|c|c|c|c|}
\hline \multicolumn{7}{|c|}{ Specific Volume of loaves } \\
\hline Source & SS & Df & MS & F-value & p-value \\
\hline Model & 4.71 & 9 & 0.52 & 10.08 & $\mathbf{0 . 0 0 3}$ \\
\hline A & 1.61 & 1 & 1.61 & 31.02 & $\mathbf{0 . 0 0 0 8}$ \\
\hline B & 0.15 & 1 & 0.15 & 2.81 & $\mathbf{0 . 0 1 3 7}$ \\
\hline C & 0.023 & 1 & 0.023 & 0.45 & $\mathbf{0 . 0 0 2 5}$ \\
\hline AB & 0 & 1 & 0 & 0 & 1 \\
\hline AC & 0.065 & 1 & 0.065 & 1.25 & 0.3001 \\
\hline BC & 0.078 & 1 & 0.078 & 1.51 & $\mathbf{0 . 0 2 5 8}$ \\
\hline $\mathrm{A}^{2}$ & 1.54 & 1 & 1.54 & 29.6 & $\mathbf{0 . 0 0 1}$ \\
\hline $\mathrm{B}^{2}$ & 0.32 & 1 & 0.32 & 6.21 & $\mathbf{0 . 0 4 1 5}$ \\
\hline $\mathrm{C}^{2}$ & 0.67 & 1 & 0.67 & 12.92 & $\mathbf{0 . 0 0 8 8}$ \\
\hline Residual & 0.36 & 7 & 0.052 & & \\
\hline Lack of fit & 0.17 & 3 & 0.056 & 1.14 & 0.4331 \\
\hline Experimental Error & 0.2 & 4 & 0.049 & & \\
\hline
\end{tabular}

$\mathrm{R}^{2}=96.84 \%$; Adjusted $\mathrm{R}^{2}=93.63 \%$; Predicted $\mathrm{R}^{2}=91.09 \%$

Values in bold form statistically different at $p<0.05$

Table 4: Estimated regression model of relationship between responses.

and loaf specific volume respectively were obtained. R-squared value is an indication of the level of responses that can be explained by a particular model. From these results, it could be shown that $92.39 \%$, $96.02 \%$ and $96.84 \%$ of the responses could be explained by the model. Statistically, the significant level obtained were $0.0037,0.004$ and 0.003 for loaf weight, volume and specific volume respectively. These levels were high and attested to the fitness of the model in evaluating the responses. The results obtained in this study revealed that the model 
employed is good and could be used for the prediction of the three selected responses (weight, volume and specific volume) from the production of wheat flour bread enriched with leafy vegetable powder.

Using the experimental data in Table 2, second degree polynomial equation model for the loaf weight, loaf volume and specific weight were regressed and the equations are shown below:

$$
\begin{aligned}
& \text { Weight of loaf }=+164.40+3.19 A-2.58 B+2.12 C-0.31 A B-1.91 A C+4.79 B C-13.28 A^{2}-9.22 B^{2}-17.50 C^{2} \\
& \text { Loaf volume }=+613.60-53.75 A+10.38 B+0.38 C+0.000 A B+12.50 A C-3.25 B C-132.67 A 2+75.93 B 2-118.42 C 2 \\
& \text { Specific volume }=+3.74-0.45 A+0.14 B-0.054 C+0.000 A B+0.13 A C-0.14 B C-0.60 A 2-0.28 B 2+0.40 C 2
\end{aligned}
$$

\section{Response surfaces analysis}

The graphical representation of 3 dimensional plots of response surface in Figures 1-3 show the relationships between the dependent and independent variables in the production of bread enriched with green leafy vegetable (fluted pumpkin) powder.

Figures 1(a) - 1(c) are three dimensional plots showing the influence of two of the variables: mixing time and level of vegetable powder inclusion on the weight, volume and the specific volume respectively of the loaves produced while the other variable, proofing time was kept constant. In Figure 1(a), increasing the mixing time of the process from 3-4.5 minutes and the level of vegetable inclusion in the composite flour from $2-4 \%$ positively affected the weight of the loaves produced. A decrease in the weight of the loaf was noticed when the mixing time was increased beyond 4.5 minutes and level of vegetable inclusion above $4 \%$. A possible explanation for this trend could be that at higher mixing time, the water absorption capacity of the composite flour protein is damaged due to over-mixing [16]. Also, from the three dimensional plots in Figure 1(a), addition of vegetable contributed immensely to the weight of the loaf probably due to its water absorption capacity.

In Figure 1(b), the effect of the mixing time and level of vegetable inclusion on the volume of the loaf is represented by three dimensional plots. In this Figure, the mixing time was seen contributing more to the volume of the loaf than the level of vegetable powder inclusion. An increase in the volume of the loaf was noticed as the mixing time increased from 3.0-4.8 minutes. The volume decreased as the mixing time approached 5.0 minutes. Mixing is an important stage in bread production. During this process, the activities of the yeast increased, more air is absorbed from the surrounding and hence the volume increased. It is also possible for the yeast to be over worked upon if the mixing time goes beyond the optimal, this might explain the reason for sharp decrease in bread volume as mixing time approached 5 minutes. The contribution of the vegetable powder to the loaf volume was peak at about 3.5\%. Addition beyond this level decreased the volume of the loaf. A possible explanation for this might be because of the replacement of the wheat flour with vegetable powder. Composite flour such as the one used in this work is a partial replacement of wheat flour with vegetable powder. One major factor that aids rising of the dough of bread is the gluten which is the protein in wheat flour. High level of vegetable powder inclusion means reduction in the level of wheat gluten and hence the rising ability of dough of bread is affected.

In Figure 1(c), the mixing time and level of vegetable powder inclusion as it affects the specific volume of the loaf is represented. It was evident from Figure 1(c) that increasing the mixing time of the process from 3-5 minutes increased the specific volume of the loaf of bread produced. However, the contribution of level of vegetable powder inclusion to the loaf specific volume of the loaf was peak at about $4.0 \%$.

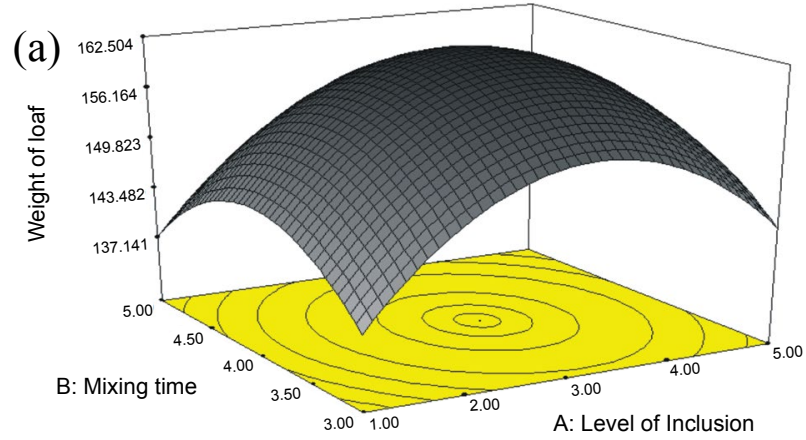

(b)

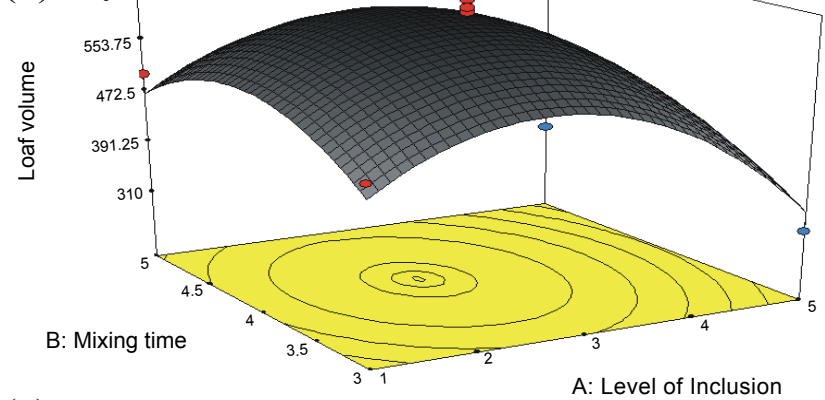

(c)

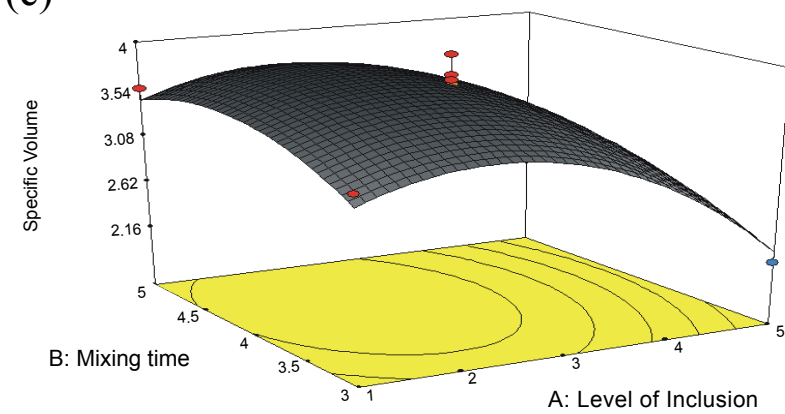

Figure 1: 3-D plot of the effect of mixing time and level of vegetable powder inclusion on loaf (a) weight (b) volume and (c) specific volume.

Figures 2(a) - 2(c) are three dimensional plots showing the loaf weight, volume and specific volume of the loaf of bread produced as functions of two variable parameters; proofing time and level of vegetable powder inclusion while keeping the mixing time of the process constant. In Figure 2(a), the loaf weight as a function of proofing time and level of vegetable inclusion is represented. The results showed increase in the weight of the loaf of bread as the proofing time increased from 60-110 minutes and level of vegetable inclusion increased from 1-4\%. Increasing the values of these variables beyond these levels resulted in negative impact on the weight of the loaves of bread. Proofing stage is an important unit operation in bread making. Under humid conditions, the release of $\mathrm{CO}_{2}$ by the yeast and the trapping of same by gluten take place at this stage. Prolong proofing time might affect the properties of bread as there might be excessive release of the gas and the gluten might be weakened.

Figure 2(b) represents the influence of the proofing time and level of vegetable powder inclusion on the volume of loaves of bread produced. It was evident from Figure 2(a) that increasing the time of proofing 60-105 minutes and the level of vegetable powder inclusion from 1.0- 


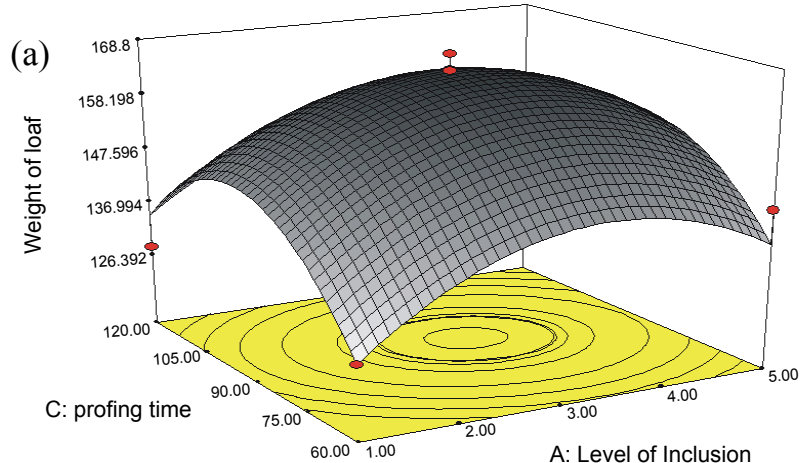

(b)
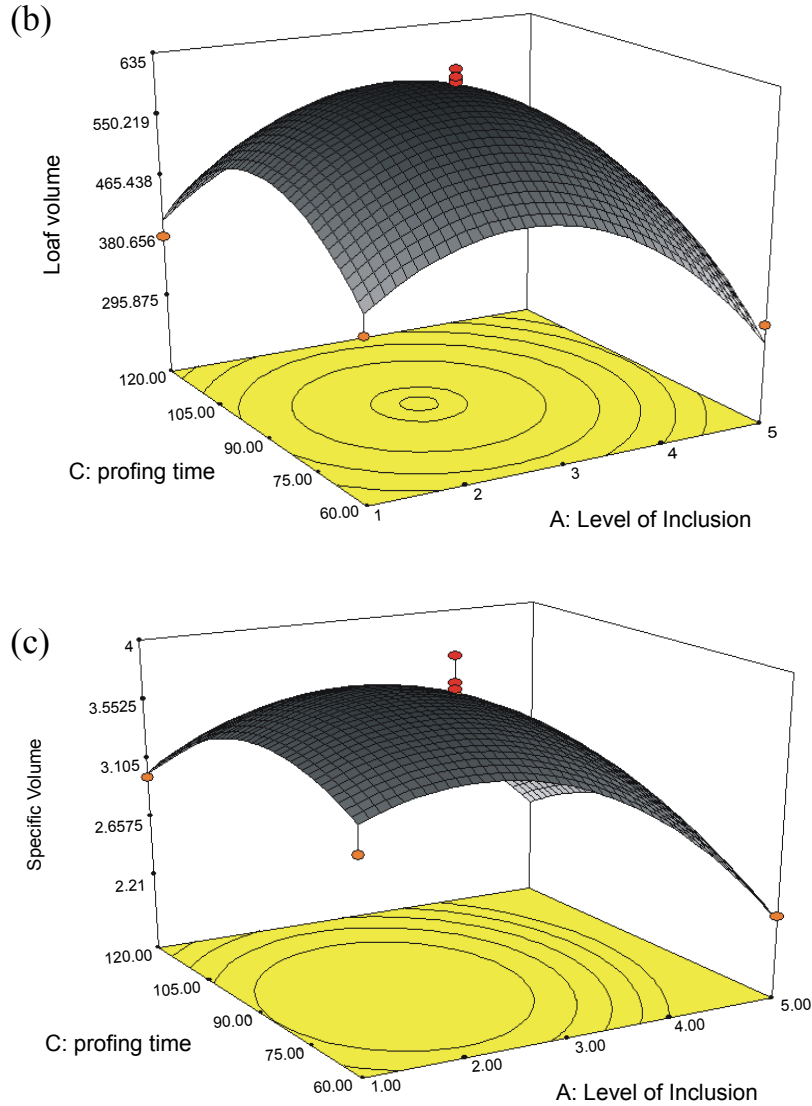

Figure 2: 3-D plot of proofing time and level of vegetable powder inclusion on the loaves (a) weight (b) volume and (c) specific volume.

$3.5 \%$ increased the loaf volume. Increasing the proofing time and level of inclusion beyond these stages lead to about $16.00 \%$ reduction in the volume of the loaf. The result agreed with the observation of Gujral and Rosell [17] on the bread made from flours composed of sorghum and wheat flours, attributing the reason to lower levels of gluten network in the dough and consequently less ability of the dough to rise; due to the weaker cell wall structure.

Specific volume of the loaf of bread as a function of proofing time and level of inclusion of the vegetable powder is shown in Figure 2(c). From the Figure, it could be observed that proofing time influenced the specific volume of the loaf of the bread more than the mixing time. Increase in the proofing time above 105 minutes and level of vegetable inclusion beyond $3.00 \%$ lead to a decrease in the specific volume of the loaf of bread. The same trend was observed when rice was composited with wheat flour in bread making [17]. Increasing the level of vegetable powder beyond this level would mean further reduction in wheat proteins. Consequently, the protein would be unable to retain gas produced during the fermentation process, resulting in a product that has a low specific volume.

Figures 3(a) - 3(c) represents the influence of proofing time and mixing time on the weight, volume and specific volume of loaf of bread produced. The results showed that proofing time had greater influence on the weight of the loaf than the mixing time as shown in Figure 3(a). The proofing time was peak at 105 minutes, after which there was progressive decrease in the weight of the loaf as the proofing time increased beyond 105 minutes. Mixing time of the process was also peak at 4 minutes. An increase in the mixing time of the process beyond this level decreased the weight of the product.

Figure 3(b) also shows the effect of proofing and mixing time on the loaf volume of the bread. There was noticeable rise in the volume of the loaf of bread when the mixing time was increased from 3 minutes to 4 minutes and the proofing time between 60 minutes to 90 minutes. As the parameters were increased beyond these levels, a decrease in the volume of the loaf was observed. A possible explanation is that over mixing might negatively affect the yeast activity and over-proofing of the dough in the prover which might affect the rising ability of the dough.

The effect of the mixing time and proofing time on the specific volume of the loaf is represented by the three dimensional plot in Figure 3(a). Mixing time of the process was seen having greater effect on the specific volume of the dough. The specific volume of the dough was on the increase as the mixing time increased and peak at about 4.5 minutes. The proofing time was also peak at about 100 minutes. Beyond these levels of proofing and mixing time, the specific volume of the loaf of bread decreased.

\section{Predictive model verification}

In verifying the capacity of the model to predict the optimum conditions for the process, maximum desirability was used for the loaf weight, volume and specific volume of the bread enriched with vegetable powder. Optimum level of vegetable powder inclusion, proofing and mixing times were generated by the software and were found to be $3.65 \%, 4.04$ minutes and 90.60 minutes respectively as shown in Table 5. With respect to these optimum conditions, the loaf volume, weight and specific volume produced were $582 \mathrm{~cm}^{3}, 163.93 \mathrm{~g}$ and $3.52 \mathrm{~cm}^{3} / \mathrm{g}$ respectively. These values were found to be close with the experimental values as shown in Table 5 . This shows the reliability of the model in optimizing the process.

\section{Comparison with conventional loaf of bread}

Table 6 shows the physical characteristic of the loaf of bread produced without the use of vegetable powder. The loaf weight of the optimized parameters with vegetable powder was more than that obtained in Table 6 without vegetable powder. The values obtained for the volumes were in close range. Comparing Table 5 and Table 6 , it is evident that the enrichment of vegetable powder in bread making, in addition to the perceived nutritional benefit, the physical characteristics of the loaf of bread is preserved.

\section{Conclusion}

Response Surface Methodology was successfully used to optimize the process condition in the production of wheat flour bread enriched with vegetable powder. The Box-Behnken design of RSM was found to 
Citation: Famuwagun AA, Taiwo KA, Gbadamosi SO, Oyedele DJ (2016) Optimization of Production of Bread Enriched With Leafy Vegetable Powder J Food Process Technol 7: 605. doi:10.4172/2157-7110.1000605

Page 6 of 7

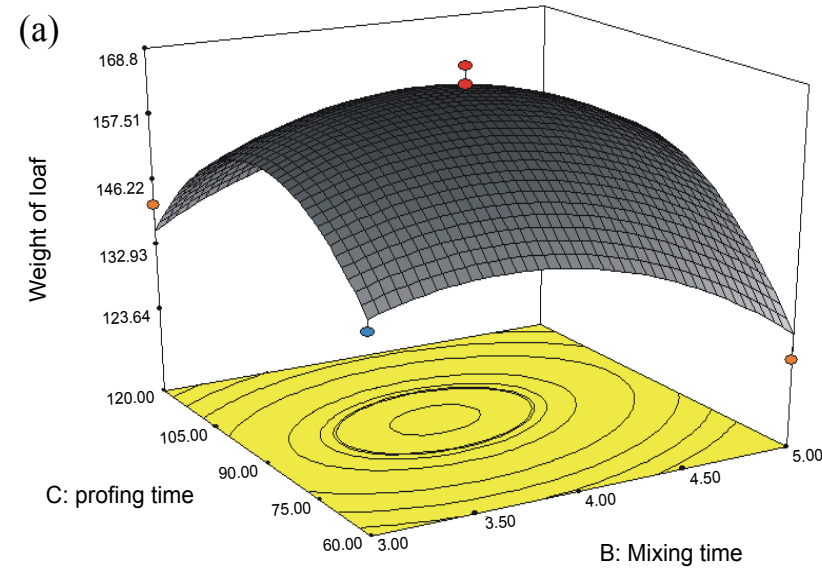

(b)

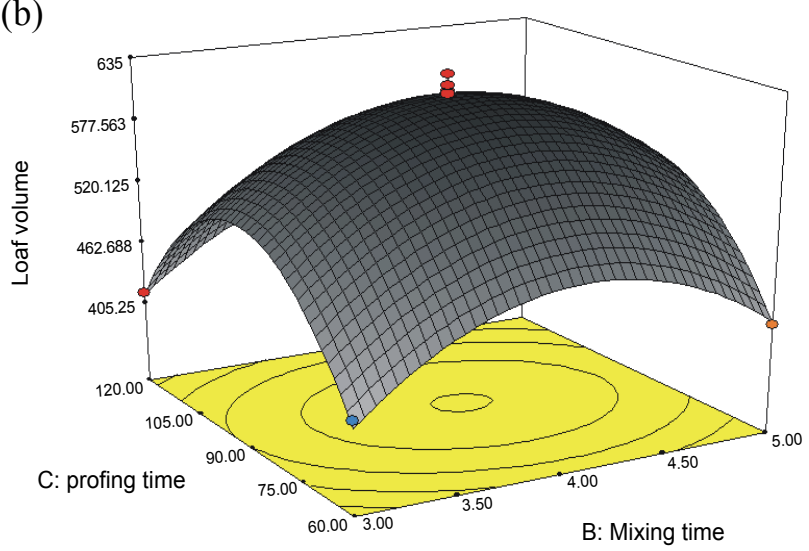

(c)

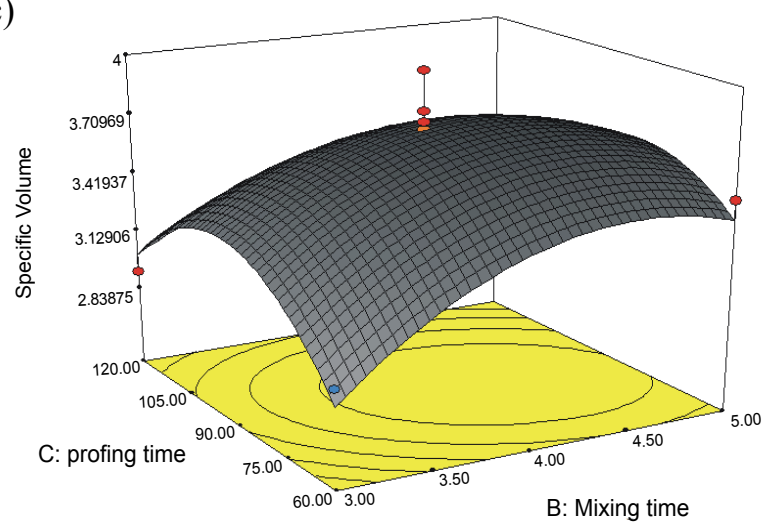

Figure 3: 3-D plots showing the influence of proofing time and mixing time of loaf (a) weight (b) volume and (c) specific volume.

\begin{tabular}{|c|c|c|}
\hline & Optimum conditions & Modified conditions \\
\hline $\begin{array}{c}\text { Mixing time }(\mathrm{min}) \\
\text { Vegetable powder inclusion } \\
(\%)\end{array}$ & 4.04 & 4 \\
\hline Proofing time $(\mathrm{min})$ & 3.65 & 3 \\
\hline Weight(g) & 90.6 & 90 \\
\hline Volume $\left(\mathrm{cm}^{3}\right)$ & $582.17 \pm 1.16$ & 164.4 \\
\hline Specific volume $\left(\mathrm{cm}^{3}\right)$ & $3.52 \pm 0.10$ & 613.6 \\
\hline
\end{tabular}

Table 5: Optimum conditions, modified conditions and the experimental value of response for the process.

\begin{tabular}{|c|c|c|c|c|c|}
\hline $\begin{array}{c}\text { Level of veg. } \\
\text { inclusion (\%) }\end{array}$ & $\begin{array}{c}\text { Mixing } \\
\text { time (min) }\end{array}$ & $\begin{array}{c}\text { Profing } \\
\text { time (min) }\end{array}$ & $\begin{array}{c}\text { Loaf weight } \\
\text { (g) }\end{array}$ & $\begin{array}{c}\text { Loaf volume } \\
\text { (cm-cube) }\end{array}$ & $\begin{array}{c}\text { Specific } \\
\text { volume }\end{array}$ \\
\hline 0 & 3 & 90 & 140.75 & 505 & 3.58 \\
\hline 0 & 4 & 90 & 135.70 & 585 & 4.31 \\
\hline 0 & 5 & 90 & 138.80 & 570 & 4.10 \\
\hline
\end{tabular}

Table 6: Control values of the experiment.

be effective to determine the level at which the vegetable powder will be added to the flour, mixing time and the proofing time of the process that will not negatively affect the physical properties of the product. The optimal conditions of the process parameters can therefore be used in the production of bread enriched with vegetable powder with acceptable physical characteristics.

\section{Acknowledgements}

Authors are grateful for funding from IDRC (International Development Research Centre) and the Department of Foreign Affairs, Trade and Development/ Canadian International Food Security Research Fund (DFATD/CIFSRF) through Project 107983 on synergizing indigenous vegetables and fertilizer micro-dosing innovations among West African farmers.

\section{References}

1. Anyika JU, Uwaegbute AC (2005) Frequency of consumption and nutrient content of some Snacks eaten by an adolescent secondary and University student in Abia State. Nig J Nutri Sci 26: 10-15.

2. Badifu SO, Chima CE, Ajayi YI, Ogori AF (2005) Influence of Mango mesocarp flour supplement to micronutrient; physical and organoleptic qualities of wheatbased bread. Nig Food J 23: 59-68.

3. Rosales-Juarez M, Gonzalez-Mendoza B, Lopez Guel EC, Lozano-Bautista F Chanonaperez J, et al. (2008) Changes on dough rheological characteristics and read quality as a result of the addition of germinated and non-germinated soybean flour Food. Bioprocess Technol 1: 152-160.

4. George P (2003) Encyclopedia of foods. Humane Press, Washington 1: 526

5. Ajibade SR, Balogun MO, Afolabi OO, Kupolati MD (2006) Sex differences in biochemical contents of Telfairia occidentalis Hook F. J Food Agri Environ 4: $155-156$.

6. USDA USDHS (2010) Dietary Guidelines for Americans (7thedn.). United States Department of Agriculture and United States Department of Health and Human Services. Washington DC, USA.

7. Shittu T, Sanni LO, Raji AO (2007) Bread from composite cassava-wheat flour: Effect of baking time and temperature on some physical properties of bread loaf. Food Res Int 40: 280-290.

8. Tekindal MA, Bayrak H, Ozkaya BGY (2012) Box- Behnken experimental design in factorial experiments: the importance of bread for nutrition and health. Turk J Field Crop 17: 115-123.

9. Carley MK, Kamneva YN, Reminga J (2004) Response surface methodology. CASOS Technical report, CMU- ISRI.

10. Li F, Yang L, Zhao T, Zou J, Zou Y, et al. (2012) Optimization of enzymatic pretreatment for $n$-hexane ex- traction of oil from Silybummarianum seeds using response surface methodology. Food Bio-prod Process 90: 87-94.

11. Zubair F, Salim R, Muhammad A (2013) Application of response surface methodology to optimize composite flour for the production and enhanced storability of leavened flat bread (Naan). J Food Process Preserv 40: 32-36.

12. Mohammed MI, Sharif N (2011) Mineral composition of some leafy vegetables consumed in Kano Nigeria. Niger J Basic Appl Sci 19: 208-211.

13. Abraham IS, Joseph OA, Dick IG (2012) Effect of Moringa oleifera leaf powder supplementation on some quality characteristics of wheat bread. Food Nutri Sci 4: 270-275.

14. Greene JL, Bovell-Benjamin AC (2004) Macroscopic and sensory evaluation of bread supplemented with sweet potato flour. J Food Sci 69: 167-173.

15. Khalil AH, Mansour EH, Dawood FM (2000) Influence of malt on rheological and baking properties of wheat-cassava composite flours. Lebens Wissen Technol 33: 159-164 
Citation: Famuwagun AA, Taiwo KA, Gbadamosi SO, Oyedele DJ (2016) Optimization of Production of Bread Enriched With Leafy Vegetable Powder. J Food Process Technol 7: 605. doi:10.4172/2157-7110.1000605

Page 7 of 7

16. Abdelghafor RF, Mustafa Al, Ibrahim AMH, Krishnan PG (2011) Quality of bread from composite flour of sorghum and hard white winter wheat. Adv $J$ Food Sci Technol 3: 9-15.
17. Gujral HS, Rosell CM (2004) Functionality of rice flour modified with a microbial transglutaminase. J Cereal Sci 39: 225-230. 